\title{
Buschke Scleredema: A new case in diabetic patient
}

\section{Samia Mrabat, Hanane Baybay, Laamari Kaoutar, Sara Elloudi, Zakia Douhi, Fatima Zahra Mernissi}

Department of Dermatology, Hassan II Hospital University, Fez, Morocco

Corresponding author: Dr. Samia Mrabat, E-mail: samiamrabat91@gmail.com

\begin{abstract}
Buschke scleredema (scleredema adultorum) is a rare pathology of unknown cause. It is characterized by sclerodermiform thickening of the cutaneous tissues mostly in the trunk and shoulder areas, with respect of the extremities. Buschke scleredema is sometimes associated with monoclonal gammopathy, diabetes or infections. This skin disease rarely involves other organs mostly the heart, but also the lungs, skeletal muscles, esophagus, parotid glands, liver, spleen, pleurae, and eyes. We report a new observation of scleroderma adultorum in a diabetic patient.
\end{abstract}

Key words: Buschke; Scleroderma; Diabetes

\section{INTRODUCTION}

Scleredema is a disorder of mucin deposition in the dermis, although there is also an abnormality in collagen deposition as well. Patients present with asymptomatic, poorly defined areas of woody skin induration that may have a orange peel appearance.

The lesions are usually localized on the neck, upper back, shoulders and arms, rarely thighs and abdomen [1]. Patients typically complain of restriction of motion of the neck and head. In contrast to systemic sclerosis, the hands and feet are not involved 5 [2]. Although scleredema classically affects the skin, extracutaneous involvement of heart, lungs, muscles and esophagus have rarely been reported [3].

\section{CASE REPORT}

A 55-year-old patient, with a history of type 2 diabetes complicated by cataract and diabetic retinopathy, presented with pruritus of the back with progressive induration of the skin evolving since 06 months. The clinical examination found thickened, indurated and difficult to pinch skin in the upper inter-scapular area, without atrophy, sweating or tenderness disorders (Fig. 1).
There were no limitations of the articular amplitudes at the level of the upper limbs. A cutaneous biopsy was performed showing thickening of the middle and deep dermis by thick bundles of collagen (Fig. 2), alcianophilic alkaline blue mucin deposits (Fig. 3), without modification of the elastic network of the dermis. The diagnosis of scleredema of the diabetic was retained. A checkup looking for clonal gammopathy was done and returned normal. The patient was placed on very potent dermocorticoids associated with colchicine with a good evolution.

\section{DISCUSSION}

Scleredema is a connective tissue disease of unknown origin that was recognized as a distinct entity by Buschke in 1902 [3]. In 1968, Graff classified the disease into three types-types I, II and III [4]. Type I, scleredema of Buschke also known as scleredema adultorum, is the most frequent one. It affects young adults mainly female and is especially found in the paediatric population and includes more than $55 \%$ of the cases. It is typically preceded by a febrile disease, many virus and bacterial agents are involved including influenza, measles, mumps, varicella, and streptococcal infections. The prognosis

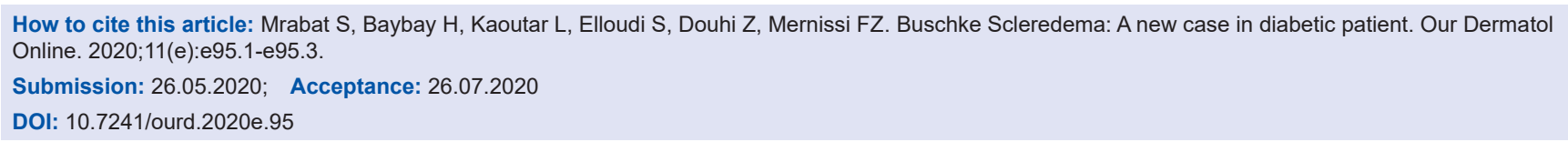




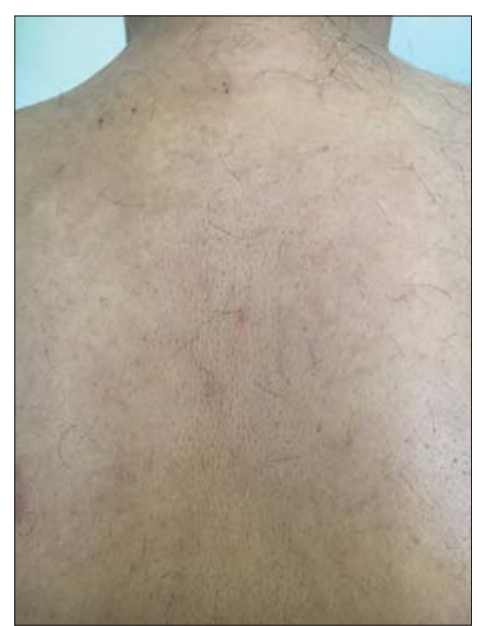

Figure 1: Induration of the interscapular area with a peau d'orange appearance.

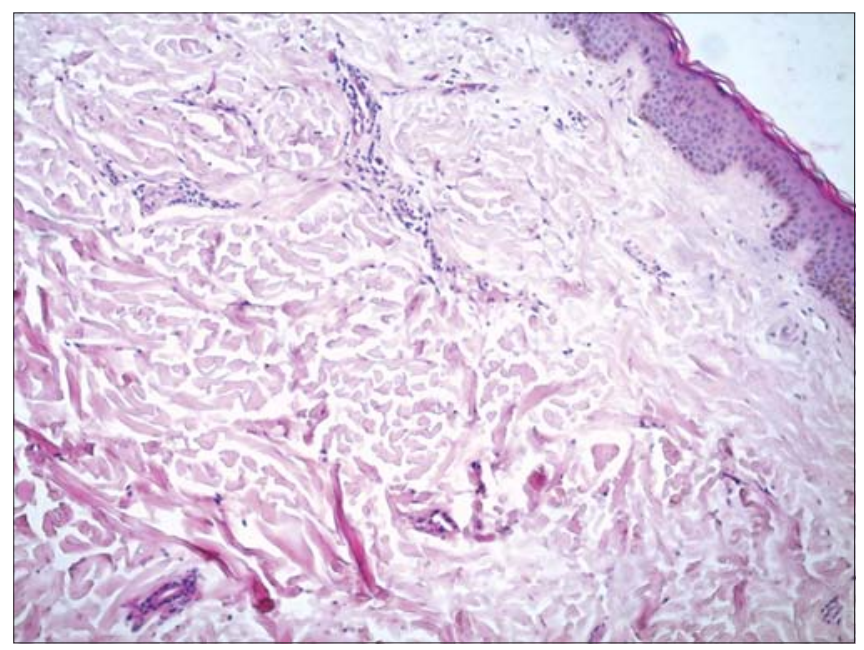

Figure 2: Collagen dense bundles of the dermis with clear spaces.

is good but a benign course, with resolution over 6 months to 2 years. Type II scleredema is associated with the development of paraproteins, most commonly hypergammaglobulinemia involving immunoglobulin $\mathrm{G}$ ( $\operatorname{IgG}$ ) k. In $25 \%$ to $45 \%$ of patients, there is progression to multiple myeloma. These patients usually have a chronic, progressive course [5]. Type III, also referred to as scleredema diabetocorum or diabetic scleredema, consists around $20 \%$ of cases and is a known, rare complication of uncontrolled diabetes mellitus. It is known to occur in $2.5 \%$ to $14 \%$ of all diabetic cases [6]. I Patients who are obese, older than 40 years, male, and have severe vascular complications of their diabetes are more likely to be affected as it was the case for our patient. In scleroderma associated with diabetes, an irreversible glycosylation of collagen as well as alterations in collagenase activity may lead to an

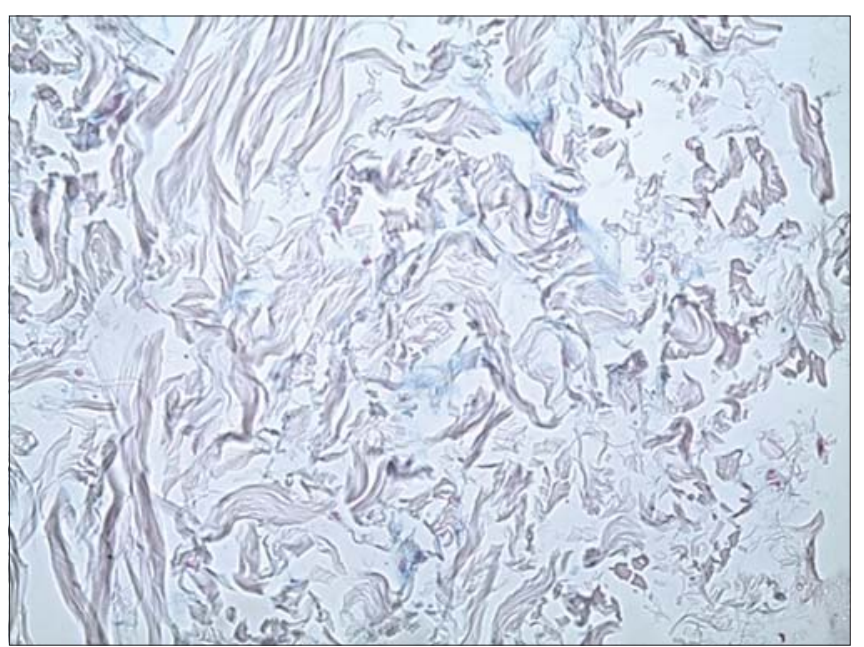

Figure 3: Slight alkaline deposits of mucin.

excessive accumulation of collagen and mucin [7]. Treatment of scleredema is very difficult. Many immunosuppressive agents have been tried, with little success. Recently, it has been reported that phototherapy UVA-1 gave good response [3]. Both tamoxifen and colchicine have been reported to have benefit as shown in our case [8]. Physical therapy, especially of the neck and shoulders, may be of benefit given the generally restrictive nature of this disorder [5].

\section{CONCLUSION}

Buschke scleredema is a rare and benign disease. It is commonly confused with conditions like scleroderma and scleromyxedema. The diagnosis can be made with careful history, clinical examination as well as the skin biopsy showing normal epidermis and thickened dermis, full of swollen collagen fibers and mucin containing clear spaces. Physical therapy should be initiated early on to minimize functional limitations in case of reduced joint mobility. Therapeutic options include phototherapy, colchicine, immunosuppressive agents such as cyclosporine, methotrexate, and systemic glucocorticoids.

\section{Consent}

The examination of the patient was conducted according to the Declaration of Helsinki principles.

The authors certify that they have obtained all appropriate patient consent forms. In the form the patient(s) has/have given his/her/their consent for his/her/their images and other clinical information to be reported in the journal. The patients understand that their names and initials will not be published and due efforts 


\section{www.odermatol.com}

will be made to conceal their identity, but anonymity cannot be guaranteed.

\section{REFERENCES}

1. Meguerditchian C, Jacquet P, Beliard S, Benderitter T, Valéro R, Carsuzzaet F, al. Scleredema adultorum of Buschke: an under recognized skin complication of diabetes. Diabetes Metab. 2006;32(5 Pt 1):481-4.

2. Beers WH, Ince A, Moore TL. Scleredema adultorum of Buschke: a case report and review of the literature. Semin Arthritis Rheum. 2006;35:355-9.

3. Yüksek J, Sezer E, Köseoğlu D, Markoç F, Yıldız H. Scleredema treated with broad-band ultraviolet A phototherapy plus colchicine. Photodermatol Photoimmunol Photomed. 2010;26:257-60.

4. Shrestha B, Neopane AK, Panth R. Scleredema--an uncommon cause of swelling in a child--a case report and review of the literature. BMC Res Notes. 2014;7:571.

5. Yaqub A, Chung L, Rieger KE, Fiorentino DF. Localized cutaneous fibrosing disorders. Rheum Dis Clin North Am. 2013;39:347-64.

6. Murphy-Chutorian B, Han G, Cohen SR. Dermatologic manifestations of diabetes mellitus: a review. Endocrinol Metab Clin North Am. 2013;42:869-8.

7. Namas R, Ashraf A. Scleredema of Buschke. Eur J Rheumatol. 2016;3:191-2.

8. Alsaeedi SH, Lee P. Treatment of scleredema diabeticorum with tamoxifen. J Rheumatol 2010;37:2636-7.

Copyright by Samia Mrabat, et al. This is an open access article distributed under the terms of the Creative Commons Attribution License, which permits unrestricted use, distribution, and reproduction in any medium, provided the original author and source are credited.

Source of Support: Nil, Conflict of Interest: None declared. 